\title{
Use of Polymerase Chain Reaction for Identification of the Pathogen and Management of Potato Soft Rot with Zinc Application
}

\author{
Ayesha Bibi1, Muhammad Junaid1, Musharaf Ahmad1, Amjad Ali2², Fazli Wahid³, \\ Rubina Naz ${ }^{4}$, Arif Ullah', Amanullah Mahar', Shahmir Ali Kalhoro' \\ ${ }^{1}$ Department of Plant Pathology, The University of Agriculture (AUP), Peshawar, Pakistan \\ ${ }^{2}$ College of Natural Resources and Environment, Northwest A\&F University, Yangling, China \\ ${ }^{3}$ Department of Soil and Environmental Sciences (AUP), Peshawar, Pakistan \\ ${ }^{4}$ Department of Botany, Kohat University of Science \& Technology, Kohat, Pakistan \\ ${ }^{5}$ College of Economics and Management, Northwest A\&F University, Yangling, China \\ ${ }^{6}$ Faculty of Agriculture, Lasbela University of Agriculture, Water \& Marine Sciences, Lasbela, Pakistan \\ Email: amjadali@aup.edu.pk
}

Received 13 March 2015; accepted 10 May 2015; published 15 May 2015

Copyright (C) 2015 by authors and Scientific Research Publishing Inc.

This work is licensed under the Creative Commons Attribution International License (CC BY).

http://creativecommons.org/licenses/by/4.0/

(c) (i) Open Access

\begin{abstract}
Effect of different Zinc doses was investigated against Erwinia carotovora ssp. atroseptica, the potato blackleg/soft rot causing organism, during 2009 and 2010 in Department of Plant Pathology and Institute of Biotechnology and Genetic Engineering, The University of Agriculture, PeshawarPakistan. Out of 200 tested samples, 21 of them were proved to be Eca. However, these tentative Eca isolates showed some characteristics which were un-expected for $E c a$. We, therefore, decided to perform Polymerase Chain Reaction using Eca-specific primers, Eca1F and Eca2R for confirm identification. For disease management, at the time of sowing, pots containing $5 \mathrm{~kg}$ sterilized soil were applied with Zinc in four different treatments i.e. $8 \mathrm{mg}, 10 \mathrm{mg}, 12 \mathrm{mg}$ and $14 \mathrm{mg}$ along with one control. Results indicated that $12 \mathrm{mg}\left(4.8 \mathrm{~kg} \mathrm{Zn} \mathrm{ha}^{-1}\right)$ were better doses in controlling the disease up to $73 \%$ and increasing the yield up to $117 \%$ as compared to control plants.
\end{abstract}

\section{Keywords}

Erwinia carotovora, Potato, PCR Identification, Soft Rot, Zinc

\footnotetext{
"Corresponding author.
}

How to cite this paper: Bibi, A., Junaid, M., Ahmad, M., Ali, A., Wahid, F., Naz, R., Ullah A., Mahar, A. and Kalhoro, S.A. (2015) Use of Polymerase Chain Reaction for Identification of the Pathogen and Management of Potato Soft Rot with Zinc Application. American Journal of Plant Sciences, 6, 1138-1143. http://dx.doi.org/10.4236/ajps.2015.68118 


\section{Introduction}

Potato (Solanum tuberosum L.) is one of the most important vegetable crops of the world. Nutritionally, potatoes are best known for their carbohydrate content and can be grown in many different environments, but it is best adapted to temperate climates [1]. The climate of Pakistan, especially of northern areas, is very suitable for the production of potatoes. Still per hectare yield of the crop is considerably low. There are different reasons for this low yield of potato crop. The prevalence of bacterial disease is one of them.

In bacterial diseases Blackleg/soft rot is one of the most important diseases of potato in Pakistan causes 10\% 30\% losses [2]. Causal agent of the disease is Erwinia carotovora ssp. Atroseptica (Eca). The pathogen is seedborne and frequently remains undetected by the common detection methods. The pathogen is found in nearly all important potato growing areas of Pakistan. The traditional identification and detection of these bacterial pathogens in seed tubers are quite laborious and not really fool-proof. Polymerase chain reaction (PCR) that rapidly detects, identifies and characterizes microorganisms in a shorter time is a good alternate for the identification purposes.

On the other hand in controlling such disease, the use of chemicals is one the most effective and quick control measure. Chemical treatment is sometimes, the only option available but not popular among the researchers, because of their residual and hazardous effects on environment.

There are different components of an IDM program but the role of micronutrients is often neglected which is the relatively safer and cheaper than any other cultural or chemical method of control. In micronutrients, Zinc is an essential element for both plants and animals. It plays an important role in several plant metabolic processes; it activates enzymes and is involved in protein synthesis and carbohydrates, nucleic acid and lipid metabolism [3] [4]. Zinc may be supplemented as a single nutrient fertilizer or as an addition to the NPK fertilizer. Research has shown that all sources of $\mathrm{Zn}$ (except granular zinc oxide) have an equal effect on crop production [5]. Recommended dosage of per hectare zinc for most of the crops is in the range of $5-34 \mathrm{~kg} \cdot \mathrm{ha}^{-1}$ (pure zinc), but keeping in mind its availability factor as $\mathrm{ZnSO}_{4}$ (with mono hydrate having $35 \%$ zinc and hepta hydrate having 22\% zinc) can be used for field application. In current studies, efforts are made to test the effect of Zinc and its optimum dose in controlling the blackleg/soft rot disease of potato.

\section{Materials and Methods}

\subsection{Isolation and Preservation of the Bacterial Isolates}

Tubers and plant samples showing disease symptoms were collected from potato growing areas of the country, in laboratory samples were cleaned, surface-sterilized with $0.5 \%$ sodium hypochlorite (for a 10 seconds), washed with sterile distilled water, placed in sterile $0.85 \%$ saline solution and crushed using sterile mortar and pestle under aseptic conditions. The resulting suspension was left undisturbed for a few minutes. A loopful of this suspension was streaked on the surface of plates containing nutrient agar (NA: Bactoagar; $10 \mathrm{gm}, \mathrm{NaCl} ; 5 \mathrm{gm}$, $\mathrm{K}_{2} \mathrm{PHO}_{4} ; 5$ gm, $\mathrm{KH}_{2} \mathrm{PO}_{4} ; 2 \mathrm{gm}$, Bactopeptone; $1 \mathrm{gm}$ ), and incubated at $28^{\circ} \mathrm{C}$ for $24 \mathrm{~h}$. In order to obtain pure culture procedure was repeated several times with growing colonies re-inoculation on media.

\subsection{Identification}

Traditional biochemical, physiological and pathological tests were applied for identification but due to overlapping results it were decided to use $E c a$-specific primers in the polymerase chain reaction to accurately confirm the identity of the pathogen. Specific primers, Eca1F (5'-CGGCATCATAAAAACACG-3') and Eca2R (5'GCACACTTCATCCAGCGA-3') as described by De Boer and Ward [6] were used for molecular identification.

For this purpose, Eca cells were grown in Luria-Bertani Broth medium (LB: tryptone at $10 \mathrm{~g} / \mathrm{L}$, yeast at $5 \mathrm{~g} / \mathrm{L}$, $\mathrm{NaCl}$ at $10 \mathrm{~g} / \mathrm{L}$; Bertani, [7]) at $27^{\circ} \mathrm{C}$ for $15 \mathrm{~h}$, DNA was extracted with commercially available DNAzol kit. The PCR master mix included $2 \mathrm{mmol} \cdot \mathrm{L}^{-1} \mathrm{MgCl}_{2}, 0.2 \mathrm{mmol} \cdot \mathrm{L}^{-1} \mathrm{dNTPs}, 1 \mu \mathrm{mol} \cdot \mathrm{L}^{-1}$ each primer, Taq buffer (67 $\mathrm{mmol} \cdot \mathrm{L}^{-1}$ Tris $\mathrm{HCl} \mathrm{pH} \mathrm{8.8)} \mathrm{and} \mathrm{5U} \mathrm{of} \mathrm{Taq} \mathrm{DNA} \mathrm{polymerase} \mathrm{were} \mathrm{added} \mathrm{to} \mathrm{each} \mathrm{PCR} \mathrm{tube} \mathrm{with} 3 \mu \mathrm{l}$ of extracted DNA. DNA amplification was performed in a MJ mini thermocycler (Bio-rad, USA) for 40 cycles and temperature $94^{\circ} \mathrm{C}$ for 30 sec denaturation, $47^{\circ} \mathrm{C}$ for 30 sec primer annealing and $72^{\circ} \mathrm{C}$ for 50 sec extension. After PCR amplification, $25 \mu \mathrm{l}$ of the product was electrophoresed on a $2 \%(\mathrm{w} / \mathrm{v})$ agarose gel as described by Sambrook et al. [7] [8]. 


\subsection{Inoculation of Seed Potato}

After successful identification bacteria was mass cultured on LB medium. Bacterial suspension $5 \times 10^{8}$ cells $\mathrm{mL}^{-1}$ $\left(\mathrm{A}_{540}=0.52\right)$ was prepared from the growing culture in $0.85 \%$ saline solution and potato tubers were washed and injured with needle and then dipped in bacterial suspension for 30 minutes and then grown.

\subsection{Zinc Application}

Inoculated potato tubers were sown in 15 inch diameter clay pots containing $5 \mathrm{~kg}$ sterilized $\left(121^{\circ} \mathrm{C}\right.$ and $15 \mathrm{lb}$ pressure for 30 mints) soil. At the time of sowing pots were applied with Zinc in four treatments i.e. $8 \mathrm{mg}, 10$ $\mathrm{mg}, 12 \mathrm{mg}$ and $14 \mathrm{mg}$ (i.e. 3.2, 4.0, 4.8 and $5.6 \mathrm{~kg} \cdot \mathrm{ha}^{-1}$ respectively) as soil application. A control with no zinc application was also included. The experiment was conducted in CR design with four replications each has 5 plants. Data was recorded for disease incidence, disease severity, yield/plant (g), fresh plant weight (g), \% germination, plant height $(\mathrm{cm})$, number of tubers per plant, tuber size and individual tuber weight $(\mathrm{g})$. For disease severity, scale [9] was used as shown in Table 1.

\section{Results}

\section{Identification of the Pathogen}

A total of 200 suspected samples obtained from soft rotted tubers and black-legged potato plants were processed. Regarding the morphology of the bacterial colonies, on NA medium the colonies appeared to be transparent, circular, raised, shiny and creamy white after $48 \mathrm{~h}$ incubation at $28^{\circ} \mathrm{C}$. Only 44 isolates were selected on morphological bases for Polymerase Chain Reaction (PCR) amplification with specific primers to confirm their identity. As clear from Figure 1, Eca-specific 690 bp band was amplified from 21 out of 44 isolates confirming that they were Eca, remaining 23 isolates might be $E c c$ or Ech according to the results of biochemical tests.

Significant differences were found among the different zinc concentrations for all the nine parameters on which the data were recorded. Over all $12 \mathrm{mg}$ zinc was found to be the most effective chemical followed by 14 and $10 \mathrm{mg}$, (Tables 2-4). In most important parameter like incidence, severity and yield, $14 \mathrm{mg}$ was found to be the most effective chemical allowing minimum disease incidence $(22.74 \%)$ in other words incidence was decreased $75.92 \%$ over control where no zinc was applied statistically similar results obtained for $12 \mathrm{mg}$ (30.55\%) however this decrease was $67.65 \%$ over the control, while maximum disease incidence was recorded for $8 \mathrm{mg}$ (70.19\%), proved to be least effective treatment.

\section{Table 1. Disease severity scale used for diseased (blackleg) plants.}

\begin{tabular}{cc} 
Scale & Description \\
\hline 0 & No blackleg/soft rot symptoms \\
1 & Less than $50 \%$ of the plant had symptoms \\
2 & More than $50 \%$ of the plant had symptoms \\
3 & Plant completely dead \\
\hline
\end{tabular}

Table 2. Effect of zinc on the disease incidence.

\begin{tabular}{|c|c|c|c|c|c|c|}
\hline Treat. & Incidence & \% Decrease & Severity & \% Decrease & Yield/plant & \% Increase \\
\hline $8 \mathrm{mg}$ & 70.19 B & $25.68^{*}$ & $2.25 \mathrm{AB}$ & 18.18 & 383.75 C & $64.00^{*}$ \\
\hline $10 \mathrm{mg}$ & $44.45 \mathrm{C}$ & $52.94^{*}$ & $1.50 \mathrm{BC}$ & $45.45^{*}$ & $452.50 \mathrm{~B}$ & $93.38^{*}$ \\
\hline $12 \mathrm{mg}$ & $30.55 \mathrm{D}$ & $67.65^{*}$ & $0.75 \mathrm{C}$ & $72.73^{*}$ & $507.50 \mathrm{~A}$ & $116.88^{*}$ \\
\hline $14 \mathrm{mg}$ & $22.74 \mathrm{D}$ & $75.92^{*}$ & $0.75 \mathrm{C}$ & $72.73^{*}$ & $483.50 \mathrm{AB}$ & $106.62^{*}$ \\
\hline Control & $94.44 \mathrm{~A}$ & -- & $2.75 \mathrm{~A}$ & -- & $234.00 \mathrm{D}$ & -- \\
\hline LSD & 12.23 & & 0.78 & & 43.66 & \\
\hline
\end{tabular}

Means followed by the same letters in columns are non-significant at $\mathrm{P} \leq 0.05$. ${ }^{*}$ Significant $(\mathrm{P} \leq 0.05)$, change over control. 
Table 3. Effect of zinc application on potato germination and yield components.

\begin{tabular}{ccccccc}
\hline Treat. & Germination & \% Increase & No. of potato & \% Increase & Height & \% Increase \\
\hline $\mathbf{8} \mathbf{~ m g}$ & $59.75 \mathrm{C}$ & $30.60^{*}$ & $6.75 \mathrm{C}$ & $80.00^{*}$ & $50.75 \mathrm{~A}$ & $20.12^{*}$ \\
$\mathbf{1 0} \mathbf{~ m g}$ & $75.50 \mathrm{~B}$ & $65.03^{*}$ & $9.50 \mathrm{~B}$ & $153.33^{*}$ & $53.50 \mathrm{~A}$ & $26.63^{*}$ \\
$\mathbf{1 2} \mathbf{~ m g}$ & $77.50 \mathrm{AB}$ & $69.40^{*}$ & $12.5 \mathrm{~A}$ & $233.33^{*}$ & $54.75 \mathrm{~A}$ & $29.59^{*}$ \\
$\mathbf{1 4} \mathbf{~ m g}$ & $84.25 \mathrm{~A}$ & $84.15^{*}$ & $6.25 \mathrm{C}$ & $66.67^{*}$ & $54.25 \mathrm{~A}$ & $28.40^{*}$ \\
$\mathbf{C o n t r o l}$ & $45.75 \mathrm{D}$ & -- & $3.75 \mathrm{D}$ & -- & $42.25 \mathrm{~B}$ & -- \\
$\mathbf{L S D}$ & 7.57 & & 2.28 & & 4.01 & \\
\hline
\end{tabular}

Means followed by the same letters in columns are non-significant at $\mathrm{P} \leq 0.05$. ${ }^{*}$ Significant $(\mathrm{P} \leq 0.05)$, change over control.

Table 4. Effect of zinc on shoot and tuber production of potato.

\begin{tabular}{|c|c|c|c|c|c|c|}
\hline Treat. & Shoot weight & \% Increase & Tuber weight & $\%$ Increase & Tuber size & \% Increase \\
\hline $8 \mathrm{mg}$ & $311.00 \mathrm{~B}$ & $52.45^{*}$ & $50.50 \mathrm{CD}$ & 23.93 & $5.02 \mathrm{~B}$ & $123.33^{*}$ \\
\hline $10 \mathrm{mg}$ & $330.75 \mathrm{AB}$ & $62.13^{*}$ & 61.25 BC & $50.31^{*}$ & $5.20 \mathrm{~B}$ & $131.11^{*}$ \\
\hline $12 \mathrm{mg}$ & $351.25 \mathrm{~A}$ & $72.18^{*}$ & $79.50 \mathrm{~A}$ & $95.09^{*}$ & $5.80 \mathrm{~A}$ & $157.78^{*}$ \\
\hline $14 \mathrm{mg}$ & $331.50 \mathrm{AB}$ & $62.50^{*}$ & $64.00 \mathrm{~B}$ & $57.06^{*}$ & $5.57 \mathrm{AB}$ & $147.78^{*}$ \\
\hline Control & $204.00 \mathrm{C}$ & -- & $40.75 \mathrm{D}$ & -- & $2.25 \mathrm{C}$ & -- \\
\hline LSD & 32.43 & & 11.14 & & 0.58 & \\
\hline
\end{tabular}

Means followed by the same letters in columns are non-significant at $\mathrm{P} \leq 0.05$. ${ }^{*}$ Significant $(\mathrm{P} \leq 0.05)$, change over control.

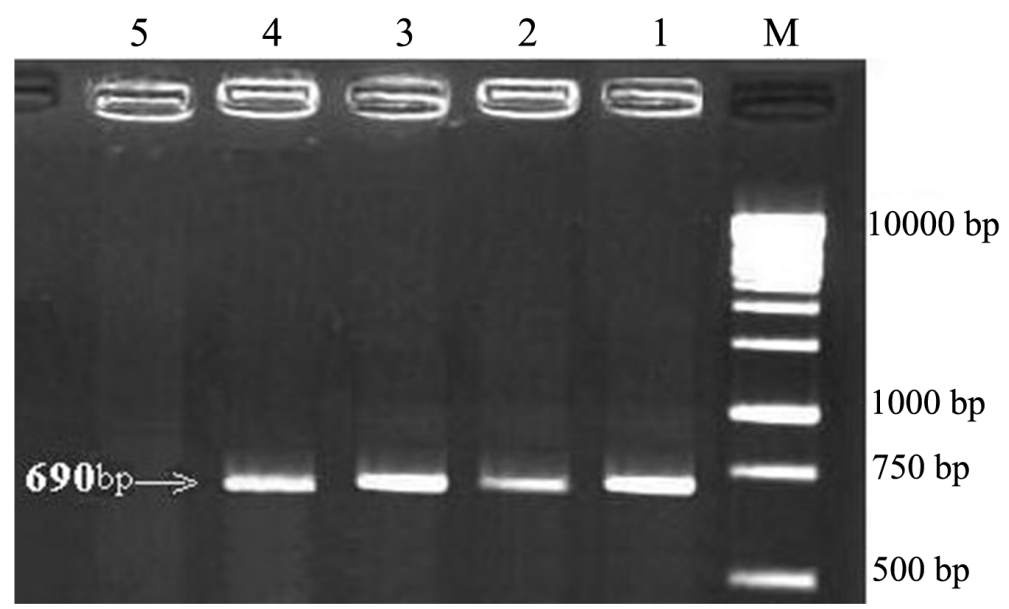

Figure 1. Amplification of Eca-specific 690 bp band.

In case of disease severity 12 and $14 \mathrm{mg}(0.75)$ were found to be most effective treatments allowing the minimum disease severity as measured according to the scale and decrease in disease severity was $72.73 \%$ as compared to control. For $8 \mathrm{mg}$ treatment the decrease over control was found to be non-significant and proved to be least effective treatment allowing maximum (2.25) amount of disease.

Plants treated with $12 \mathrm{mg}$ zinc gave maximum yield ( $507.5 \mathrm{~g} / \mathrm{plant}$ ) followed by $14 \mathrm{mg}$ zinc applied plants (483.5 g/plant) in both cases the increase in yield was more than $100 \%$ as compared to control plants. For other parameters shown in Table 3 and Table 4 like Germination, Numbers of potatoes/plant, shoot weight, Individual tuber weight, and Tuber size. Similar results were obtained i.e. 12 and $14 \mathrm{mg}$ application of zinc was found to bring positive change and significant results were obtained over control plants. However, plant height was found 
to be non-significant for all the treatment, shows that zinc has no effect on plant height.

\section{Discussion}

To control a plant disease effectively, accurate and timely diagnosis is a must. In case of plant bacterial diseases, a series of biochemical, physiological, pathogenic and other tests are done to accurately diagnose the causal organism. In the present studies, a large number of such tests were conducted to identify the pathogen but the actual causal organism Erwinia carotovora ssp. atroseptica was often misidentified because of the two other species of the pathogen E. c. carotovora and E. chrysanthemi although key diagnostic tests such as acid production from $\alpha$-methyle glucoside, production of reducing substances from sucrose, sensitivity to erythromycin and growth at $36^{\circ} \mathrm{C}$ were performed. But the results were quite conflicting, similar results were also obtained with Lelliot and Dicky [10] and Perombelon and Kelman [11]. But when our key diagnostic tests gave overlapping results regarding the identity of blackleg/soft rot causal organism an alternate quick, accurate and sophisticated approach was followed and that is Polymerase Chain Reaction (PCR) was performed (using Eca-specific primers) for all the isolates to confirm their identity. The $690 \mathrm{bp}$ Eca-specific DNA band [7] was amplified from 21 isolates out of 44, confirming that they were Eca. The fact that we can successfully and accurately identify the potato-blackleg/soft rot causal organism using Eca-specific primers and our optimized PCR conditions has important implications for seed certifying agencies doing seed-potato indexing.

Management of a disease to bring yield and quality losses to a minimum possible level is a challenging job. Some diseases are especially difficult to control because each of the different available control measures contributes very little. Black leg/soft rot of potato is one of such hard-to-control diseases. A disease like potato black leg can only be successfully controlled if an integrated disease management program (IDM) is followed. There are different components of an IDM program but the role of micronutrients is often neglected which is the relatively safer and cheaper than any other cultural or chemical method of control. In micronutrients, zinc is involved in numerous aspects of cellular metabolism. It is required for the catalytic activity of approximately 100 enzymes [12] and it plays a role in immune function [13], DNA synthesis, protein synthesis, and cell division [14].

For this reason, it was decided to investigate the potential of zinc to control black leg/soft rot of potato caused by Eca. Finding a better chemical/nutrition to control a disease in not enough, it should also be known that what dose should be used. The dose studies indicated that $4.8 \mathrm{~kg} / \mathrm{ha}(12 \mathrm{mg} / \mathrm{kg}$ soil) soil applied zinc was effective in controlling the Eca infection in potato plants and recommended for field application but its reaction with other macro and micronutrients should also be investigated. It is also suggested that a range of micronutrients should be tested to find which one can be used in to control plant bacterial diseases and at the same time avoid the easy development of chemical resistance in phyto-pathogenic bacteria.

\section{Conclusion}

From the above studies, it is concluded that zinc has a high potential to manage black leg/soft rot of potato caused by Eca. However, the effective dose for soil applied zinc should be $4.8 \mathrm{~kg} / \mathrm{ha}$ (12 mg/kg soil) while managing the disease down to its minimum.

\section{References}

[1] De Boer, S.H. and Ward, L.J. (1995) PCR Detection of Erwinia carotovora Subsp. Atroseptica Associated with Potato Tissue. Phytopathology, 85, 854-858. http://dx.doi.org/10.1094/Phyto-85-854

[2] George, H. and Schmitt, M. (1997) Zinc for Crop, WW-00720-GO.

[3] Haverkort, A.J. (1990) Ecology of Potato Cropping Systems in Relation to Latitude and Altitude. Agriculture Systems, 32, 251-272. http://dx.doi.org/10.1016/0308-521X(90)90004-A

[4] Lelliott, R.A. and Dickey, R.S. (1984) Genus VII. Erwinia. In: Krieg, N.R. and Holt J.G., Eds., Bergey’s Manual of Systematic Bacteriology, Williams \& Wilkins, Baltimore, 469-476.

[5] Marschner, H. (1986) Mineral Nutrition of Higher Plants. Academic Press, New York.

[6] Pahlsson, A.M.B. (1989) Toxicity of Heavy Metals (Zn, Cu, Cd, Pb) to Vascular Plants. Water Air Soil Pollution, 47, 287-319. http://dx.doi.org/10.1007/BF00279329

[7] Bertani, G. (1951) Studies on Lysogenesis. I. The Mode of Phage Liberation by Lysogenic Escherichia coli. Journal of 
Bacteriology, 62, 293-300.

[8] Perombelon, M.C.M. and Kelman, A. (1980) Ecology of the Soft rot Erwinias. Annual Review Phytopathology, 18, 361-387. http://dx.doi.org/10.1007/BF00279329

[9] Prasad, A.S. (1995) Zinc: An Overview. Nutrition, 11, 93-99.

[10] Sambrook, J. Fritsch, E.F. and Maniatis, T. (1989) Molecular Cloning: A Laboratory Manual. 2nd Edition, N.Y. Cold Spring Harbor Laboratory, Cold Spring Harbor.

[11] Sandstead, H.H. (1994) Understanding Zinc: Recent Observations and Interpretations. Journal of Laboratory and Clinical Medicine, 124, 322-327.

[12] Solomons, N.W. (1998) Mild Human Zinc Deficiency Produces an Imbalance between Cell-Mediated and Humoral Immunity. Nutrition Reviews, 56, 27. http://dx.doi.org/10.1111/j.1753-4887.1998.tb01656.x

[13] Turkensteen, L.J. (1986) Survey on Bacterial and Fungal Diseases of Potato in the Hilly Area of Pakistan. PakistanSwiss Potato Development Project Booklet, 1-41, Publisher-PARC.

[14] Wright, P.J., Triggs, C.M. and Burg, G.K. (2005) Control of Bacterial Soft Rot of Calla (Zantedeschia spp.) by Pathogen Exclusion, Elimination and Removal. New Zealand Journal of Crop and Horticultural Science, 33, 117-123. http://dx.doi.org/10.1080/01140671.2005.9514340 